\title{
NEW CONVENIENT VAPOR PRESSURE-TEMPERATURE CORRELATION FOR SOME ALIPHATIC HYDROCARBONS
}

\author{
Jane B. Bogdanov and Bogdan T. Bogdanov
}

Research Laboratory for Petroleum Derivatives and Fuel Analysis, Institute of Chemistry, Faculty of Natural Sciences and Mathematics, Ss. Cyril and Methodius University, 1000 Skopje, Republic of Macedonia j_b_bogdanov@yahoo.com

New empirical equations for correlating temperature dependence of vapor pressure for $\mathrm{C}_{6}-\mathrm{C}_{20}$ aliphatic hydrocarbons are proposed:

$$
\ln (V P)=\frac{k_{1} \cdot T}{k_{2}+T}
$$

where $V P$ - vapor pressure, $T$ - temperature, $k_{1}$ - asymptotic maximum vapor pressure, and $k_{2}$ - temperature at which the vapor pressure has half of its maximum value.

Descriptors $k_{1}, k_{2}$ and $k_{1} / k_{2}$ have physical meaning and are unique for a given liquid. This "uniqueness" can be exploited for quantitative description of vapor pressure-temperature curve. The equation given above can be transformed algebraically into other convenient forms for plotting experimental data such as:

$$
\begin{aligned}
& \frac{T}{\ln (V P)}=a+b \cdot T \\
& k_{1}=\frac{1}{b} \quad ; \quad k_{2}=\frac{a}{b}
\end{aligned}
$$

where $a$-intercept; $b$ - slope.

These derived descriptors can be utilized for evaluation and comparison of properties of different liquids and liquid mixtures and can serve as additional parameters for analysis of liquid hydrocarbon-based fuels for internal combustion engines.

Keywords: vapor pressure; vapor pressure-temperature equations; aliphatic hydrocarbons

\section{НОВА ПОГОДНА КОРЕЛАЦИЈА ПАРЕН ПРИТИСОК-ТЕМПЕРАТУРА ЗА НЕКОИ АЛИФАТИЧНИ ЈАГЛЕВОДОРОДИ}

Предложени се нови емпириски равенки за корелирање на температурната зависност на парниот притисок за јаглеводородите $\mathrm{C}_{6}-\mathrm{C}_{20}$ :

$$
\ln (V P)=\frac{k_{1} \cdot T}{k_{2}+T},
$$


каде што се: $V P$ - парен притисок, $T$ - температура, $k_{1}$ - асимптотски максимален парен $\bar{u} и \bar{u} и с о к$, $k_{2}$ - температура на која парниот притисок има половина од неговата максимална вредност.

Дескрипторите $k_{1}, k_{2}$ and $k_{1} / k_{2}$ имаат физичко значење и се карактеристични за дадена течност. Оваа посебност може да биде искористена за квантитативен опис на кривата парен притисоктемпература. Равенката дадена погоре може да биде алгебарски трансформирана во други погодни форми за графичко прикажување на експериментални податоци како што се, на пример:

$$
\begin{aligned}
& \frac{T}{\ln (V P)}=a+b \cdot T \\
& k_{1}=\frac{1}{b} \quad ; k_{2}=\frac{a}{b}
\end{aligned}
$$

каде што се: $a$ - пресек со ординатата; $b$ - наклон.

Овие изведени дескриптори можат да бидат употребени за евалуација и споредување на својствата на различни течности или смеси од течности и можат да служат како додатни параметри за анализа на течни јаглеводородни горива наменети за мотори со внатрешно согорување.

Клучни зборови: парен притисок; равенки парен притисок-температура; алифатични јаглеводороди

\section{INTRODUCTION}

The vapor pressure of pure organic liquid is a useful thermodynamic parameter that can be related to many other properties. The vapor pressure-temperature relationship for pure liquids is of great importance in many areas of science and engineering. There have been many different representations of the vapor pressure-temperature relationship for pure liquids. For this purpose, the most frequently used representation is the Antoine equation [1], where the relation between vapor pressure and temperature for pure components is described in the following manner:

$$
\ln (V P)=A-\frac{B}{C+T}
$$

where $V P$ is the vapor pressure, $T$ is temperature and $A, B$ and $C$ are component-specific constants.

The simplified form with $C$ set to zero is given bellow:

$$
\ln (V P)=A-\frac{B}{T}
$$

The Antoine equation can also be transformed into a temperature-explicit form with simple algebraic manipulations:

$$
T=\frac{B}{A-\ln (V P)}-C \text {. }
$$

The described vapor pressure is not continuous at the normal boiling point, and the deviation between calculated and real vapor pressures increases. The solution for this problem is switching to another vapor pressure equation with more than three parameters. To overcome the limits of the Antoine equation some simple extensions by addition of more terms are used. Wagner equations [2] (Equations 4 and 5) contain such simple extensions:

$V P=\exp \left(A-\frac{B}{C+T}+D \cdot T+E \cdot T^{2}+F \cdot \ln (T)\right)$

$$
V P=\exp \left(A-\frac{B}{C+T}+D \cdot \ln (T)+E \cdot T^{F}\right)
$$


The additional parameters increase the flexibility of the equation and allow the description of the entire vapor pressure curve. The extended equation forms can be reduced to the original form by setting the additional parameters $D, E$ and $F$ to 0 . Additional difference is that the extended equations use $E$ as base for the exponential function and the natural logarithm. This does not affect the equation form. An excellent summary of the main vapor-pressure equations proposed in the literature up to 1994 can be found in the paper by Xiang and Tan [3]. There are many other papers in the literature on this subject. However, the publications connected and relevant to this study are given in references 4-17, 20, 21.

Even though the vapor pressure curve can be satisfactorily described by the above mentioned equations, these equations are not convenient for practical applications, especially for mixtures of hydrocarbons. Most of the existing methods for analysis of quality and performance of liquid hydrocarbon-based fuels (as specified in ASTM D6378, EN13016-2) demand measurements of the tendency of vapor pressure of the liquid over a selected temperature range. As a result of these measurements a vapor pressure temperature curve is generated, which is an important parameter for quality control of fuels. Our intention was to develop equations which can more conveniently describe the experimental parameters obtained in the above described measurements and which can be extended to hydrocarbon mixtures. The aim of our work is to develop a new empirical and statistically reliable equation to express the dependence of vapor pressure-temperature experimental data for aliphatic $\mathrm{C}_{6}-\mathrm{C}_{20}$ hydrocarbons.

\section{RESULTS AND DISCUSSION}

As a starting point of the study the aliphatic $\mathrm{C}_{6}-\mathrm{C}_{20}$ hydrocarbons were selected because they are the main constituents of the liquid fuels for internal combustion engine. Additionally, reliable experimental vapor pressure data needed for this theoretical approach were avail- able from the literature [18]. The observed vapor pressure-temperature experimental data were fitted to many $\ln (V P)$ vs. temperature equations by a least-squares regression method using the STATGRAPHICS Centurion XVI Program [19]. We have found that Equation 6 was a statistical expression representing the vapor pressure-temperature experimental data:

$$
\ln (V P)=\frac{k_{1} \cdot T}{k_{2}+T} .
$$

This equation defines the quantitative relationship between the vapor pressure and temperature, if both coefficients $k_{1}$ and $k_{2}$ are known. The general principles of mathematics are applicable to this relationship. In Figure 1 the effect of temperature on the vapor pressure can be observed. At moderate temperatures (about $90{ }^{\circ} \mathrm{C}$ to $150^{\circ} \mathrm{C}$ ) the vapor pressure is proportional to the temperature. However, as the temperature increases, the vapor pressure falls off and is no longer proportional to the temperature. With further increase in temperature, the vapor pressure becomes almost constant and independent of temperature. We refer to this point (coefficient $k_{1}$ ) as a maximum vapor pressure of the liquid. All liquids have this point, and it is specific for each liquid. Therefore, $k_{1}$ is a specific coefficient for each liquid and has dimension of vapor pressure.

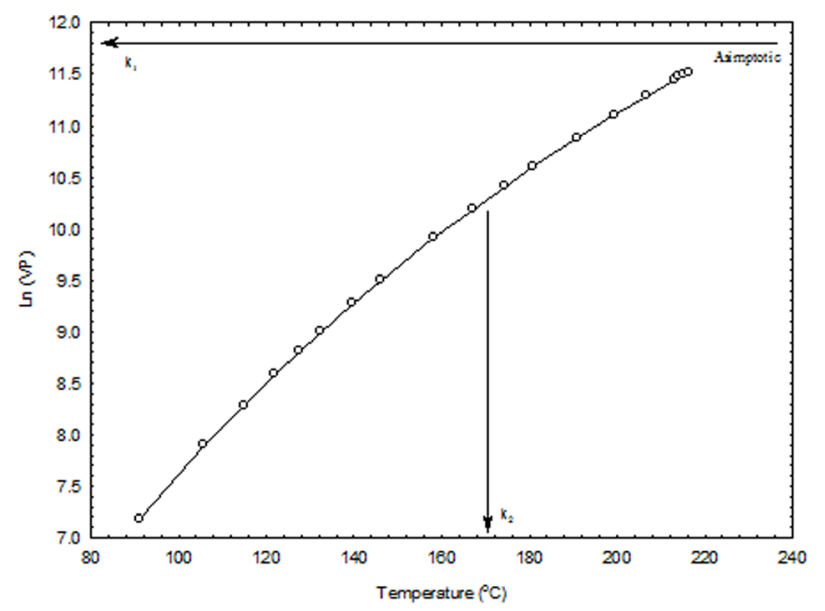

Fig 1. Effect of temperature on natural logarithm of vapor pressure for $n$-dodecane. $k_{1}$ - asymptotic maximum vapor pressure, $k_{2}-$ expresses the temperature at which the vapor pressure has half of its maximum value 
An important numerical relationship emerges from Equation 6 in special case when $\ln (V P)=k_{1} / 2$, we then have:

$$
\frac{k_{1}}{2}=\frac{k_{1} \cdot T}{k_{2}+T}
$$

If we divide Equation 7 by $k_{1}$, we obtain:

$$
\frac{1}{2}=\frac{T}{k_{2}+T} .
$$

By rearranging Equation 8 we obtain:

$$
k_{2}+T=2 \cdot T, \text { or } \quad k_{2}=T \text {. }
$$

We may therefore conclude that $k_{2}$ is equal to the temperature at which the vapor pressure has half of its maximum value. Obviously, $k_{2}$ has the dimension of temperature. Figure 1 shows that $k_{2}$ can be extrapolated graphically from data on the effect of temperature on the vapor pressure $[\ln (V P)]$. Note that $k_{2}$ is not a fixed value, it may vary with the properties of the liquids and liquids have a characteristic $k_{2}$ coefficient. The $k_{1} / k_{2}$ ratio is also a very important descriptor for vapor pressure properties. Therefore, $k_{1}, k_{2}$ and $k_{1} / k_{2}$ coefficients can be used in the evaluation of pure liquid hydrocarbons and can be potentially extended for evaluation of liquid hydrocarbonbased fuels. The values of $k_{1}$ and $k_{2}$, together with the $k_{1} / k_{2}$ give the general profile of the vapor pressure temperature curve. This kind of description (profile) is especially important for comparison of properties of different liquids and can be extended to liquid mixtures.

\subsection{Application of Equation (6)}

Experimental data for aliphatic hydrocarbons used in this theoretical approach was obtained from the work by Zwolinski and Wilhoit [18]. The results obtained by applying of Equation 6 for $k_{1}, k_{2}$ and $k_{1} / k_{2}$ estimation are given in Table 1. In Figure 2 it can be seen that the curve generated $(\ln (V P)$ vs. temperature) from experimental data for $n$-dodecane and the curve generated from the fitted Equation 6 are almost the same, which is supported by statistical parameters $\left(R^{2}=99.9989, s=0.0046\right.$, $\left.r_{\text {pred/obs }}=0.999995\right)$. From these results it became evident that a convenient vapor pressure-temperature correlation as expressed by equation 6 for $\mathrm{C}_{6}-\mathrm{C}_{20}$ aliphatic hydrocarbons was established.

Next we wanted to see if the derived descriptor $k_{1}$ (asymptotic maximum vapor pressure) is related to a meaningful and measurable physical property, such as boiling point. From Figure 3 (plot of boiling point vs. $k_{1}$ ) and from the statistical parameters $(r=0.994)$ it is obvious that $k_{1}$ has physical meaning.

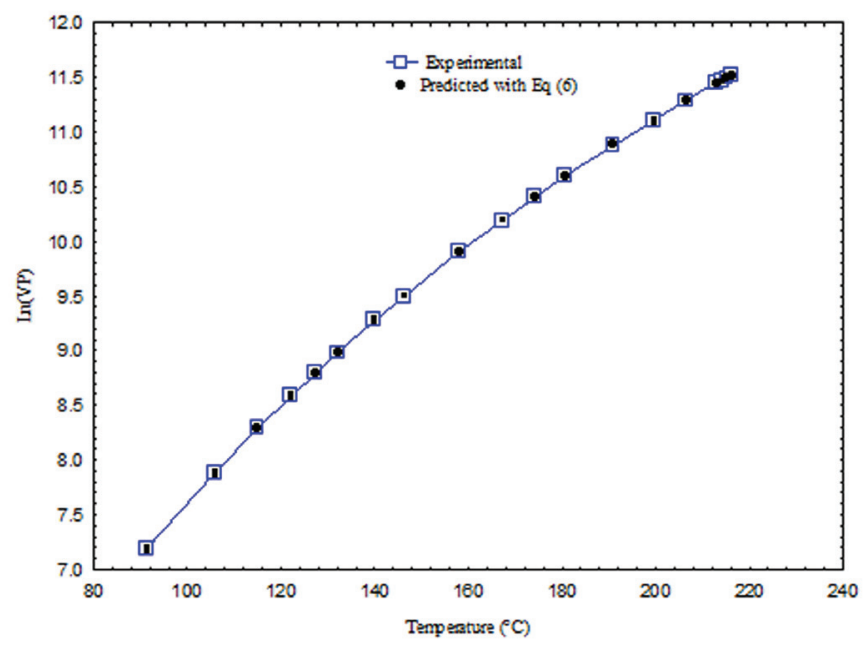

Fig. 2. Effect of temperature on natural logarithm of vapor pressure for $n$-dodecane. Experimental values were obtained from the literature [18].

\subsection{Transformation of Equation 6}

The Equation 6 can be transformed algebraically and tested statistically into other forms that are more useful for plotting experimental data, for example Equation 10 to Equation 13:

$$
\frac{1}{\ln (V P)}=\frac{k_{2}+T}{k_{1} * T}
$$


Ta a le 1

Statistical parameter for fitting of 16 experimental data vapor pressure vs. temperature using Equations 6 and 13 for some aliphatic hydrocarbons

\begin{tabular}{|c|c|c|c|c|c|c|c|c|c|}
\hline & Alkane & Eq. & Intercept & Slope & $k_{1}$ & $k_{2}$ & $R^{2}$ & $s$ & $r_{\text {obs/pred }}$ \\
\hline \multirow{2}{*}{1} & \multirow{2}{*}{ Isohexane } & $(6)$ & - & - & - & - & - & - & - \\
\hline & & (13) & -0.315 & 0.097 & 10.288 & -3.247 & 98.563 & 0.369 & 0.9928 \\
\hline \multirow{2}{*}{2} & \multirow{2}{*}{$n$-Hexane } & $(6)$ & - & - & - & - & - & - & - \\
\hline & & (13) & -0.174 & 0.094 & 10.684 & -1.862 & 98.664 & 0.348 & 0.9933 \\
\hline \multirow{2}{*}{3} & \multirow{2}{*}{ 3,3-Dimethylpentane } & $(6)$ & - & - & - & - & - & - & - \\
\hline & & (13) & 0.170 & 0.088 & 11.364 & 1.934 & 98.845 & 0.325 & 0.9942 \\
\hline \multirow{2}{*}{4} & \multirow{2}{*}{ n-Heptane } & $(6)$ & - & - & - & - & - & - & - \\
\hline & & (13) & 0.661 & 0.083 & 12.125 & 8.016 & 99.011 & 0.282 & 0.9950 \\
\hline \multirow{2}{*}{5} & \multirow{2}{*}{ n-Octane } & $(6)$ & - & - & 13.331 & 23.552 & 91.866 & 0.389 & 0.9713 \\
\hline & & $(13)$ & 1.954 & 0.073 & 13.780 & 26.920 & 99.293 & 0.218 & 0.9965 \\
\hline \multirow{2}{*}{6} & \multirow{2}{*}{$n$-Nonane } & $(6)$ & - & - & 15.057 & 48.826 & 98.405 & 0.177 & 0.9922 \\
\hline & & (13) & 3.312 & 0.066 & 15.220 & 50.405 & 99.581 & 0.162 & 0.9979 \\
\hline \multirow{2}{*}{7} & \multirow{2}{*}{$n$-Decane } & $(6)$ & - & - & 16.859 & 82.290 & 99.589 & 0.090 & 0.9980 \\
\hline & & (13) & 4.897 & 0.059 & 16.902 & 82.764 & 99.790 & 0.107 & 0.9949 \\
\hline \multirow{2}{*}{8} & \multirow{2}{*}{ n-Undecane } & (6) & - & - & 18.727 & 123.313 & 99.926 & 0.038 & 0.9996 \\
\hline & & (13) & 6.581 & 0.053 & 18.723 & 123.221 & 99.936 & 0.056 & 0.9997 \\
\hline \multirow{2}{*}{9} & \multirow{2}{*}{$n$-Dodecane } & (6) & - & - & 20.673 & 171.804 & 99.999 & 0.005 & 0.9999 \\
\hline & & $(13)$ & 8.309 & 0.048 & 20.670 & 171.734 & 99.999 & 0.008 & 0.9999 \\
\hline \multirow{2}{*}{10} & \multirow{2}{*}{$n$-Tridecane } & (6) & - & - & 22.838 & 230.369 & 99.978 & 0.021 & 0.999 \\
\hline & & (13) & 10.102 & 0.044 & 22.877 & 231.107 & 99.957 & 0.040 & 0.9998 \\
\hline \multirow{2}{*}{11} & \multirow{2}{*}{$n$-Tetradecane } & $(6)$ & - & - & 25.060 & 296.165 & 99.923 & 0.039 & 0.9996 \\
\hline & & (13) & 11.860 & 0.040 & 25.182 & 298.657 & 99.782 & 0.083 & 0.9989 \\
\hline \multirow{2}{*}{12} & \multirow{2}{*}{$n$-Pentadecane } & $(6)$ & - & - & 27.542 & 373.615 & 99.855 & 0.054 & 0.9993 \\
\hline & & (13) & 13.641 & 0.036 & 27.798 & 379.191 & 99.431 & 0.125 & 0.9972 \\
\hline \multirow{2}{*}{13} & \multirow{2}{*}{$n$-Hexadecane } & (6) & - & - & 30.315 & 464.012 & 99.781 & 0.066 & 0.9989 \\
\hline & & (13) & 15.424 & 0.033 & 30.768 & 474.555 & 98.828 & 0.165 & 0.9941 \\
\hline \multirow{2}{*}{14} & \multirow{2}{*}{ n-Heptadecane } & (6) & - & - & 32.727 & 550.884 & 99.720 & 0.074 & 0.9986 \\
\hline & & $(13)$ & 16.989 & 0.030 & 33.396 & 567.362 & 98.099 & 0.200 & 0.9905 \\
\hline & & $(6)$ & - & - & 35.438 & 650.388 & 99.641 & 0.084 & 0.9982 \\
\hline 15 & $n$-Octadecane & (13) & 18.557 & 0.027 & 36.415 & 675.745 & 96.920 & 0.239 & 0.9845 \\
\hline & & $(6)$ & - & - & 47.890 & 1074.460 & 99.515 & 0.098 & 0.9976 \\
\hline 16 & n-Eicosane & (13) & 22.772 & 0.020 & 50.647 & 1153.350 & 90.627 & 0.313 & 0.9520 \\
\hline
\end{tabular}

$$
\ln (V P)=a+b \frac{\ln (V P)}{T}
$$

In Equation 11: $k_{1}=$ intercept $(a) ; k_{2}=\operatorname{slope}(b)$

$$
\frac{1}{\ln (V P)}=a+b \frac{1}{T}
$$

In Eq. (12): $\quad k_{1}=\frac{1}{a} ; k_{2}=\frac{b}{a}$

$$
\frac{T}{\ln (V P)}=a+b \cdot T
$$




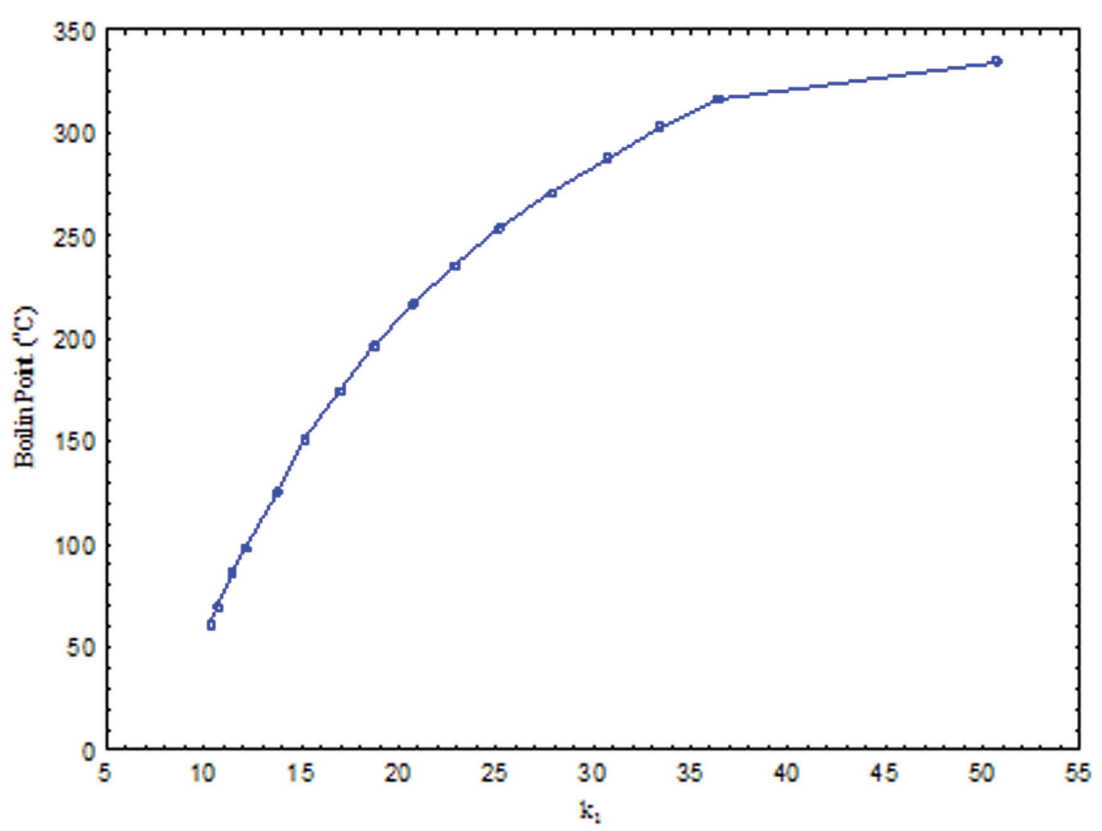

Fig. 3. Boiling point vs. $k_{1}$ plot; [boiling point $=-161.5+78.4 * \sqrt{ }\left(k_{1}\right)$ ], $r=0.97$. The open circles in the plot correspond to the hydrocarbons given in Table 1 and are given in ascending order.

A statistical evaluation of these above mentioned graphical methods for determining $k_{1}$, and $k_{2}$ shows that the Equation 13 is the most satisfactory and gave the most accurate values of these quantities over the usual range of temperature and vapor pressure available from experimental data (Figure 4).
This equation has a high correlation coefficient $(r)$ and very small standard deviation (Table 1). Although, it may not be inferior to Equation 6 in terms of $k_{1}$, and $k_{2}$ evaluation quality, it has an advantage that $k_{1}$, and $k_{2}$ can be easily calculated from the straight line with a slope of $1 / k_{1}$, and an intercept of $k_{2} / k_{1}$, and of -

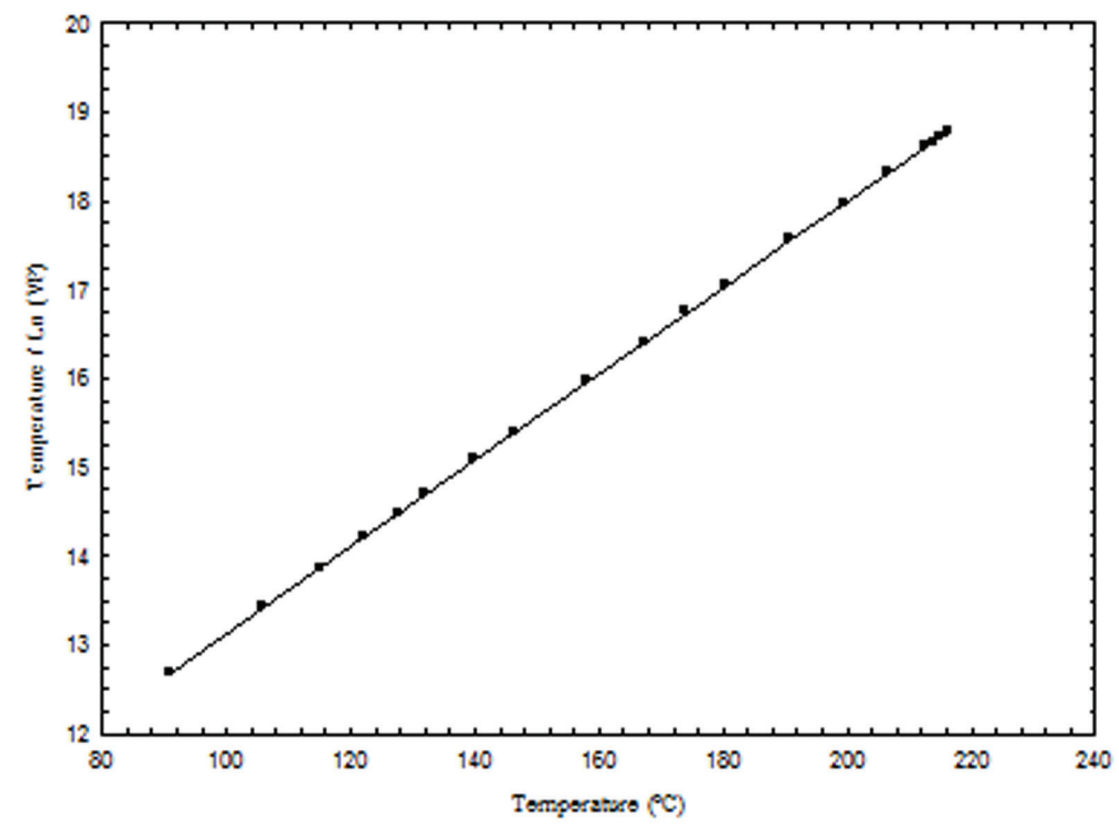

Fig. 4. Plot of $\frac{T}{\ln (V P)}$ versus $T$, according to the Eq. (13). $k_{1}=\frac{1}{b} ; k_{2}=\frac{a}{b}$ for $n$-dodecane 
$k_{2}$ on ordinate and on the abscissa, respectively, without having any statistical computing package.

The statistics for $n$-dodecane using Equation 13 indicates that the model as fitted explains $99.9986 \%$ of the variability in $T / \ln (V P)$. The correlation coefficient equals 0.999993, indicating a relatively strong relationship between the variables. The standard error of the estimate shows the standard deviation of the residuals to be 0.0078 . Similar statistical parameters were obtained for the other aliphatic hydrocarbons (Table 1) indicating that the developed model is applicable from $\mathrm{C}_{6}$ to $\mathrm{C}_{20}$. The strong relationship between the variables means that even with fewer experimentally obtained data points, the coefficients $k_{1}$ and $k_{2}$ can be determined with satisfactory accuracy, which in turn will be sufficient to describe the vapor pressure-temperature dependence.

\section{CONCLUSION}

New empirical equations (6 and 13) for correlating temperature dependence of vapor pressure for $\mathrm{C}_{6}-\mathrm{C}_{20}$ aliphatic hydrocarbons are proposed. From these equations, $k_{1}$ (asymptotic maximum vapor pressure) and $k_{2}$ (temperature at which the vapor pressure has half of its maximum value) descriptors were obtained. These descriptors together with the $k_{1} / k_{2}$ are unique for a given liquid. This "uniqueness" can be exploited for quantitative description of vapor pressure-temperature curve. As an outcome of this, these descriptors can be utilized for evaluation and comparison of properties of different liquids and liquid mixtures. This feature is particularly appealing to complement the existing methods for evaluation and analysis of liquid hydrocarbon-based fuels (ASTM D6378, EN13016-2) which demand measurements of vapor pressure tendency of the liquid over a selected temperature range.

\section{REFERENCES}

[1] C. Antoine, Tensions des vapeurs; nouvelle relation entre les tensions et les temperatures, Comptes Rendus des Séances de l'Académie des Sciences, 107, 681-684, 778-780, 836-837 (1888).

[2] W. Wagner, New vapour pressure measurements for argon and nitrogen and a new method for establishing rational vapour pressure equations, Cryogenics, 13, 470-482 (1973).

[3] H.W. Xiang, L. C. Tan, A new vapor-pressure equation, Int. J. Thermophys., 15, 711-727 (1994).

[4] B. E. Poling, J. M. Prausnitz, J. P. O'Connell, The properties of gases and liquids, McGraw-Hill, New York, 2001, pp. 7.1-7.13.

[5] G. A. Iglesias-Silva, J. C. Holste, P. T. Eubank, K. N. Marsh, K. R. Hall, A vapor pressure equation from extended asymptotic behavior, AIChE J, 33, 1550-1556 (1987).

[6] R. D. Shaver, R. L. Robinson, K. A. M. Gasem, A framework for the prediction of saturation properties: vapor pressures, Fluid Phase Equilibr, 64, 141-163 (1991).

[7] G. A. Iglesias-Silva, R. C. Miller, A. D. Ceballos, K. R. Hall, J. C. Holste, Accurate vapor pressure equation for refrigerants, Fluid Phase Equilibr., 111, 203-212 (1995).

[8] J. M. Ledanois, C. M. Colina, J. W. Santos, D. González-Mendizabal, C. Olivera-Fuentes, New expressions for the vapor pressure of pure components constructed on characteristic points, Ind. Eng. Chem. Res., 36, 2505-2508 (1997).

[9] H. Korsten, Internally consistent prediction of vapour pressure and related properties, Ind. Eng. Chem. Res., 39, 813-820 (2000).

[10] M. Frenkel, G. A. Iglesias-Silva, M. S. Mannan, K. R. Hall, Fitting vapor pressure - temperature data: simplicity and unintended consequences, Fluid Phase Equilibr. 183-184, 217-228 (2001).

[11] H. W. Xiang. Vapor pressures from a corresponding-states principle for a wide range of polar molecular substances, Int. J. Thermophys., 22, 919-932 (2001).

[12] E. Voutsas, M. Lampadariou, K. Magoulas, D. Tassios, Prediction of vapor pressures of pure compounds from knowledge of the normal boiling point temperature, Fluid Phase Equilibr., 198, 81-93 (2002).

[13] A. J. Queimada, E. H. Stenby, I. M. Marrucho, J. A. P. Coutinho. A new corresponding states model 
for the estimation of thermophysical properties of long-chain $n$-alkanes, Fluid Phase Equilibr., 212, 303-314 (2003).

[14] K. Mejbri, A. Bellagi, Corresponding states correlation for the saturated vapor pressure of pure fluids, Thermochim. Acta, 436, 140-194 (2005).

[15] J. T. Wu, Z. G. Liu, An accurate vapor pressure equation with good extrapolation characteristics, Int. J. Thermophys., 26, 767-784 (2005).

[16] E. D. Rogdakis, P. A. Lolos, Simple generalized vapour pressure and boiling point correlation for refrigerants, Int. J. Refrig., 29, 632-634 (2006).

[17] S. S. Godavarthy, R. L. Robinson, K. A. M. Gasem, SVRC-QSPR model for predicting vapor pressures of pure fluids, Fluid Phase Equilibr., 246, 39-51 (2006).
[18] B. J. Zwolinski, R. C. Wilhoit, Handbook of vapor pressures and heats of vaporization of hydrocarbons and related compounds, API-44 TRC Publication No. 101, Texas A\&M University, Evans Press, Fort Worth, Texas (1971).

[19] STATGRAPHICS Centurion XVI, StatPoint Technologies, Inc. (2010).

[20] H. Eslami, Equation of state for nonpolar fluids: prediction from boiling point constants, Int. J. Thermophys., 21,1123-1137 (2000).

[21] R. Span, W. Wagner, Equations of state for technical applications. II. Results for nonpolar fluids, Int. J. Thermophys., 24, 41-109 (2003). 